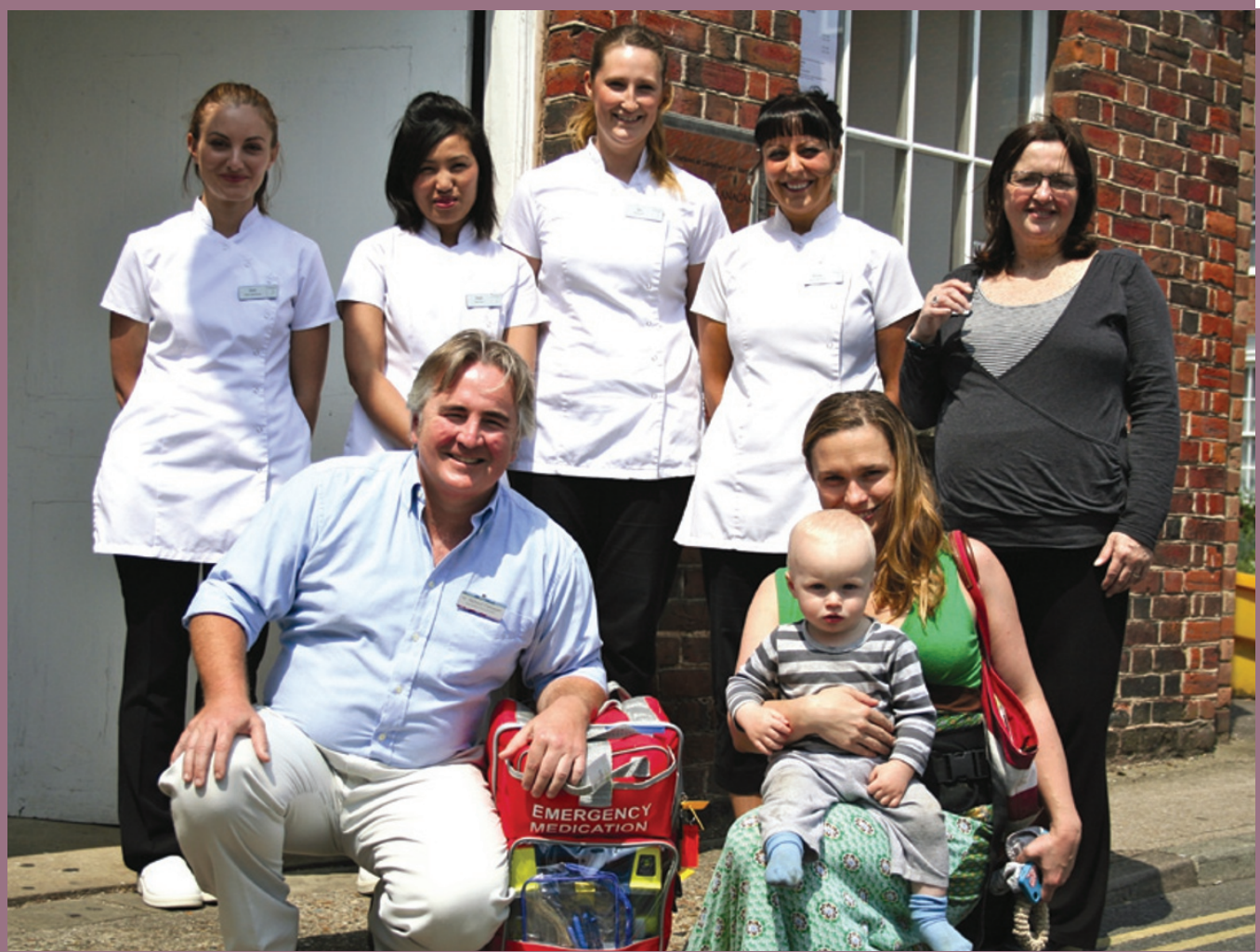

Back row l-r: Sarah Lindley (senior nurse), Sheila Gurung (dental nurse), Sam Mitchell (dental nurse), Michelle Kennett (senior nurse), Julia Whitehead (practice manager). Front row l-r: Dr Richard Flanagan (specialist orthodontist) and Agnes Wrodarczyk with her son Henry

\section{NEW EDUCATIONAL OPPORTUNITIES FOR DENTAL TECHNICIANS}

The Dental Technologists Association (DTA) and UMD Professional have announced the launch of a new joint initiative to provide verifiable continuing professional development (CPD) to dental technicians with a management role in their laboratory. The modules can be taken on their own but can also be grouped together to achieve the Institute of Leadership and Management (ILM) Diploma in Management through the completion of a series of work-based assignments.

In addition, technicians who successfully complete the level 5 Diploma can build on their qualification with further distance learning study at UMD Professional's partner university to achieve a BA (Hons) in Business Management or Professional Studies.

'The DTA has extended its educational role through this new initiative and we are pleased to have developed this programme in association with UMD Professional to provide further benefits for our members,' said Barry Appleby, President of the DTA.

For more information contact Penny Parry at UMD Professional on 02082552070

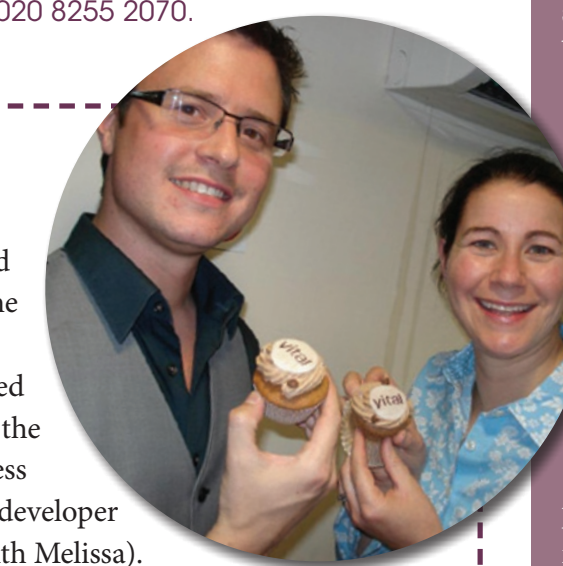

\section{'THE BABY JUST SPRANG TO LIFE'}

The dental team at the Richard Flanagan and Associates orthodontic practice in King Street, Canterbury, put their medical emergencies training to good use when they brought a 10-month-old local child back to life.

Canterbury resident Agnes Wrodarczyk was at home with her baby son Henry on 19 April when he appeared to suffer a seizure and his heart and breathing stopped. Panicking, Agnes and her partner Adrian Littler rang 999 then decided to take Henry to the nearby orthodontic practice.

Specialist orthodontist Dr Richard Flanagan and senior dental nurse Michelle Kennett performed CPR and managed to resuscitate Henry. By coincidence, the dental team had attended their annual medical emergencies update just one week earlier.

'After about 30-40 compressions the baby just sprang to life,' said Dr Flanagan. It was the most amazing feeling. After ensuring the airway

was clear of obstruction, we initiated CPR with 4-5 rescue breaths via an ambu bag. The important thing to remember is to ensure the lungs are inflating either with air or positive pressure oxygen, which is what we used in Henry's case.'

Paramedics arrived and Henry was taken to Ashford Hospital, where he spent the night. He has since made a full recovery. It is believed that the seizure may have been caused by a virus.

Jo Williams, the Private Practice Manager at the practice, said that the incident highlighted the importance of regular training in emergency procedures for the dental team. 'Especially as in this instance, it was a member

of the general public and not a patient who accessed the surgery, reflecting the general public's reliance on dental professionals as individuals who should be competent in coping with medical emergencies. charity Bridge2Aid with a raffle.

Dental Angels Recruitment's

Chief Executive, Kelly in the cover story of the Vital, officially 'switched on' the new website at th event alongside busines Iain Scott (pictured with Melissa)

Partygoers enjoyed some Vital branded cupcakes specially made for the occasion - but Editor Kate Maynard pointed out on Vital's Facebook page that Vital does not endorse sugary snacks as anything more than an occasional treat! www.dentalangels.co.uk 